\title{
Pysiological Responses of Diploid and Triploid Far Eastern Catfish, Silurus asotus to Water Temperature Stress
}

\author{
Hyo Bin Lee', Dong Soo Kim², Hyun Woo Gil ${ }^{3}$, and ${ }^{\dagger}$ In-Seok Park ${ }^{4}$ \\ ${ }^{I}$ Dept. of Fisheries Biology Center for Risk Assessment of Oceans and Fisheries Living Modified Organisms, \\ Pukyong National University, Busan 48513, Korea \\ ${ }^{2}$ Dept. of Marine Bio-Materials \& Aquaculture, Pukyong National University, Busan 48513, Korea \\ ${ }^{3}$ Bio-Monitoring Center, Sejong 30121, Korea \\ ${ }^{4}$ Division of Marine Bioscience, College of Ocean Science and Technology, Korea Maritime and Ocean University,
} Busan 49112, Korea

\begin{abstract}
The aim of study is to contribute to this knowledge-base by investigating the respiratory function, the metabolic rate and the difference of physiological responses un-der low water temperature $\left(20^{\circ} \mathrm{C} \rightarrow 15^{\circ} \mathrm{C}\right)$ stress be-tween diploid and triploid far eastern catfish, Silurus asotus. During the $48 \mathrm{hrs}$ of water temperature stress exposure time, the respiratory frequencies, $\mathrm{CO}_{2}$ and $\mathrm{NH}_{4}{ }^{+}$concentrations of diploid had higher values than those of triploid $(p<0.05)$. However, $\mathrm{pH}$ of triploid was higher than those of diploid $(p<0.05)$, and oxygen consumption rate was not different between diploid and triploid $(p>0.05)$. The level of plasma cortisol and plasma glucose of triploid was lower than those of the diploid $(p<0.05)$. However, in case of lactic acid, there were not significant between triploid and diploid $(p>0.05)$. These results suggest that diploid was more sensitive for low water temperature stress response than triploid in this species.
\end{abstract}

Key words : Diploid, Far eastern catfish, Physiological response, Respiratory function, Temperature stress, Triploid

\section{INTRODUCTION}

The far eastern catfish, Silurus asotus is a member of the freshwater family Siluridae, and is an important commercial catfish in Korea (Kim et al., 2001). Average annual production of this species by culture in Korea was 5,139 tons at 2017 (Korean Statistical Information Service, 2017). The market demand for this species has gradually expanded in recent years. However, the following two major limitations may reduce the profits of far eastern catfish culture. First, there is a sex-related dimorphism in the growth rate, i.e., females grow much faster than males (Kim et al., 2001). This leads to difficulty in effective stock management and frequently results in severe cannibalism in farms during the early stages of life. Second, precocious maturation prior to the fish reaching marketable size necessitates an extended cultivation period beyond sexual maturity. Upon attaining sexual maturity, these fish begin to experience reduced growth and decreased feeding efficiency (Choi et al., 1992). Therefore, the induction of triploidy offers more rapid growth and added value due to the increased production of larger catfish (Lim et al., 2017).

\footnotetext{
Manuscript received January 7, 2018, Received in revised form April 10, 2018, Accepted May 30, 2018

${ }^{\dagger}$ Corresponding Author : In-Seok Park, Division of Marine Bioscience, College of Ocean Science and Technology, Korea Maritime and Ocean University, Busan 49112, Korea. Tel: +82- 51-410-4321, Fax: +82- 51-404-4750, E-mail: ispark@kmou.ac.kr
}

This is an Open Access article distributed under the terms of the Creative Commons Attribution Non-Commercial License (http:// creative-commons.org/licenses/by-nc/3.0) which permits unrestricted non-commercial use, distribution, and reproduction in any medium, provided the original work is properly cited. 
Triploidization is a technique used to generate sterile aquatic animals by taking advantage of the incompatibility in pairing the three homologous chromosomes during meiosis I (Don \& Avtalion, 1986). This technique has also been used to enhance the productivity of several fish species because of its assumed ability to increase yield by channeling the energy required from gonadal development to somatic growth (Tave, 1993; Gil et al., 2017; Lim et al., 2017). More importantly, it generates fish that are unable to breed and contribute to the local gene pool if they were to accidentally escape from confinement. By conferring sterility of exotic fish for a limited purpose, triploidy can serve as an effective method for reducing or eliminating the environmental risks of genetically modified organisms (Dunham \& Devlin, 1999).

In intensive culture systems fish are continuously exposed to stress (Gamperl et al., 1994), including increased density, inadequate nutrition, poor sanitation, injury during handling, high water temperature or low water temperature. Stress responses can include physiological changes such as oxygen uptake and transfer, metabolic and hematological changes, mobilization of energy substrates, reallocation of energy away from growth and reproduction, and suppressive effects on immune functions (Pickering \& Pottinger, 1989; Barton \& Iwama, 1991). These changes can increase disease susceptibility leading to increased mortality and subsequent economic losses.

Knowledge of the oxygen consumption rate of a species is of great interest in aquaculture, since it represents an indication of the metabolic expenditure of animals to maintain their vital functions through an aerobic metabolism (Brett \& Groves, 1979). In the specific case of crustaceans, oxygen consumption is influenced by environmental factors such as oxygen concentration, temperature, salinity or the light-dark cycle, as well as by intrinsic factors such as bodyweight, activity level, feeding state, moulting cycle or biological rhythms (Daoud et al., 2007; Li et al., 2007; Perera et al., 2007). In addition, manipulation and the type of feed supplied may provoke significant changes in oxy- gen consumption (Hewitt \& Irving, 1990). Oxygen consumption per unit weight is an objective and versatile characteristic describing the level of metabolism. Rate of gas exchange gives an indication of energy expenditure on the life-supporting functions associated with growth, feeding and reproduction. It is correlated with such important economic criteria as survival, productivity and growth rate (Kazakov \& Khalyapin, 1981). The physiological response of fish under stress can be sorted by first, second, and third responses (Barton \& Iwama, 1991). The first response is to increase internal secretion activities by promoting the secretion of catecholamine and glucocorticoid, thus inducing the second response where the fish then undergoes metabolic and hematological changes which subsequently induce the final and third response by which time the fish starts to exhibit obvious signs of stress and discomfort (Thompson et al., 1993).

For the purpose of our investigation the commercially important far eastern catfish was chosen as the case-study species. Seol et al. (2008) has been able to show that the diploid and triploid far eastern catfish does exhibit haematological parameters and respiratory function such as erythrocyte nuclear size, oxygen consumption rate and respiratory frequency. However, previous research on far eastern catfish has no investigated comparative analysis of respiratory function and metabolic rate between diploid and triploid. Thus, we have determined to examine the comparative analysis of respiratory function and metabolic rate between diploid and triploid in far eastern catfish. That is, the aims of this study are to ascertain if triploid induces respiratory function and metabolic rate change and to contribute to this knowledge-base by investigating the difference of physiological responses under low water temperature stress between diploid and triploid far eastern catfish.

\section{MATERIALS AND METHODS}

On June 14, 2010, triploid induction of the far eastern 
catfish, Silurus asotus was carried out according to the method of Kim et al. (2001). Mature females were induced to spawn using a single intraperitoneal (IP) injection of 1,000 IU of human chorionic gonadotropin (hCG, Sigma, USA) per kg body weight (BW). Sperm were obtained by cutting the surgically removed testes of males that had been given an IP injection of hCG at $500 \mathrm{IU} / \mathrm{kg} \mathrm{BW.} \mathrm{Eggs}$ were fertilized with sperm diluted in saline using the wet method. Five minutes after fertilization, the eggs were rinsed rapidly to remove excess sperm and were immediately subjected to cold-shock treatment $\left(4^{\circ} \mathrm{C}\right)$ for $60 \mathrm{~min}$ to prevent the extrusion of the second polar body. Untreated fertilized eggs were used as diploid controls.

Diploid and triploid individuals $(n=100)$ were cultivated by the method of Kim et al. (2001). All fish were reared in 450-L tanks under the same hydrological conditions. Water temperature was maintained at $20 \pm 1.5^{\circ} \mathrm{C}$, and the mean water oxygen concentration was kept close to saturation level (mean \pm SD : $9.4 \pm 0.3 \mathrm{mg} / \mathrm{L})$. Fish were periodically sampled and their ploidy was determined by flowcytometric assessment (PA II, Partec, Germany) of the nuclear DNA content in erythrocytes or fin cells. For water temperature stress test, 4 - year - olds of 100 far eastern catfish in diploid and triploid, respectively. Standard length (mean \pm SD) of used samples were $59.67 \pm 5.91 \mathrm{~cm}$ in diploid and $75.13 \pm 8.69 \mathrm{~cm}$ in triploid, respectively. Body weights (mean \pm SD) of used samples were $574.1 \pm 55.89 \mathrm{~g}$ in diploid and 893.5 $\pm 78.11 \mathrm{~g}$ in triploid, respectively. During the experiment, to avoid sampling fish with metabolism that were changed by large quantities of food, fish were starved for $24 \mathrm{hrs}$ before experiment. Water temperature in the two rectangular glass tanks (Dimensions $\mathrm{W} 200 \times \mathrm{L} 69 \times \mathrm{H} 47 \mathrm{~cm})$ were reached $15^{\circ} \mathrm{C}$ by cooler and 30 samples of each ploidy was transfer immediately in each rectangular glass tanks. After experiment started, measurement times were chosen at $6 \mathrm{hrs}$ intervals over $48 \mathrm{hrs}$.

The respirometer chamber was utilized by a simple sealed container. The respirometer chamber was comprised of an acrylic resin box with a thickness of $8 \mathrm{~mm}$; the over-

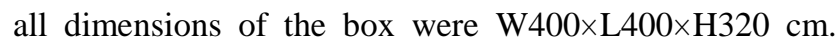
The hose of inflow water was equipped with a temperature controller and $10 \mu \mathrm{m}$ and $3 \mu \mathrm{m}$ cartridge filters equipped for the exclusion of particles. The flow-through UV lamp was utilized for the reduction of oxygen consumption by microbes. Water from the respirometer chamber flowed into an oxygen measurement chamber. Prepared respirometer chambers were categorized by measurement time and ploidy and sex. Water temperatures of each group were matintained $20 \pm 0.5^{\circ} \mathrm{C}$ by heater.

Before measuring dissolved oxygen, $\mathrm{pH}$, ammonium $\left(\mathrm{NH}_{4}{ }^{+}\right)$concentration and carbon dioxide $\left(\mathrm{CO}_{2}\right)$ concentration, respiratory frequency (gill cover movement) was measured using a counter and a digital timer. $\mathrm{NH}_{4}{ }^{+}$and $\mathrm{CO}_{2}$ concentrations were measured using spectrophotometer (DR2800, HACH, Loveland, Colorado, USA). Dissolved oxygen and $\mathrm{pH}$ was measured using an oxygen measurement electrode and a multi-data logger system (Oxyguard, Denmark). Measurements of oxygen and oxygen consumption rates at each experimental group were saved by the multi-data logger, as described Schreck (1982).

$$
\begin{aligned}
& \text { Oxygen consumption rate }(\mathrm{mg} \mathrm{O} / \mathrm{h})= \\
& \left(\mathrm{CO}_{2}(\mathrm{~A})-\mathrm{CO}_{2}(\mathrm{~B})\right) \times \mathrm{V} / \mathrm{T} ;
\end{aligned}
$$

$\mathrm{CO}_{2}(\mathrm{~A})=$ Dissolved oxygen concentration of water at the start of the measurement period, $\mathrm{mg} / \mathrm{L} ; \mathrm{CO}_{2}(\mathrm{~B})=$ Dissolved oxygen concentration of water at the end of the measurement period, $\mathrm{mg} / \mathrm{L} ; \mathrm{V}=$ Volume of respiremeter, $\mathrm{L} ; \mathrm{T}=\mathrm{Time}$ elapsed during measurement period, $\mathrm{h}$.

Blood samples were extracted from five randomly selected fish at 0 (pre), 1, 6, 12, 24, and $48 \mathrm{hrs}$ post low water temperature stress test. Using syringes lined with the anticoagulant heparin blood was extracted and assayed at fixed intervals of $0,1,6,12,24$ and $48 \mathrm{hrs}$ from five experimental samples. Selected blood was filled into capillary tubes and analyzed after centrifuging at $200 \mathrm{~g}$ for 10 
minutes. Plasma was then collected and stored in a deep freezer (SW-UF-200; Samwon Freezing Engineering, Busan, Korea) at $-80^{\circ} \mathrm{C}$ until analysis. The cortisol concentration was measured using radioimmunoassay. Cortisol was determined in $50 \mu \mathrm{L}$ samples using RIA kits (Coat-A-Count TKCO Cortisol RIA Kit; DPC, USA). Mixtures of sample in $100 \mathrm{~mL}$ antiserum were incubated for $45 \mathrm{~min}$ at $37^{\circ} \mathrm{C}$, and then $1,000 \mathrm{~mL}$ separation reagent was added. The mixture was placed in a refrigerator at $4{ }^{\circ} \mathrm{C}$ for $15 \mathrm{~min}$ and then centrifuged at $1,200 \mathrm{~g}$ for $15 \mathrm{~min}$. Supernatant was assayed for gamma radiation using an automatic gamma counter (Cobra; Packard, USA). Plasma glucose concentration was analyzed according to methodology of Raabo and Terkildsen (1960; Kit 510, Sigma, St Louis, MO, USA), where production of $\mathrm{H}_{2} \mathrm{O}_{2}$ by glucose oxidase in the presence of $o$-dianisidine was evaluated as an absorbance increase at $450 \mathrm{~nm}$. The lactic acid concentrations were analyzed using blood automatic analysis (Boehringer Mannhein Reflotron, Germanry).

Using the SPSS statistics package (SPSS 12.0, SPSS Inc., Chicago, IL, USA), one-way analysis of variance (ANOVA) were carried out to test for statistical significance $(p<0.05)$ between diploid and triploid fish. Multiple comparisons were performed using Duncan's multiple range test (Duncan, 1955). All experiments were performed triplicate.

\section{RESULTS}

During the low water temperature stress test, the respiratory frequencies of diploid and triploid far eastern catfish, Silurus asotus increased until $12 \mathrm{hrs}$ and then decreased gradually until $48 \mathrm{hrs}$, respectively (Fig. 1). The respiratory frequency was affected by ploidy, and the respiratory frequencies of diploid were lower than triploid while 30 hrs $(p<0.05)$. After $36 \mathrm{hrs}$, the respiratory frequencies were not significantly different between diploid and triploid during $12 \mathrm{hrs}(p>0.05)$.

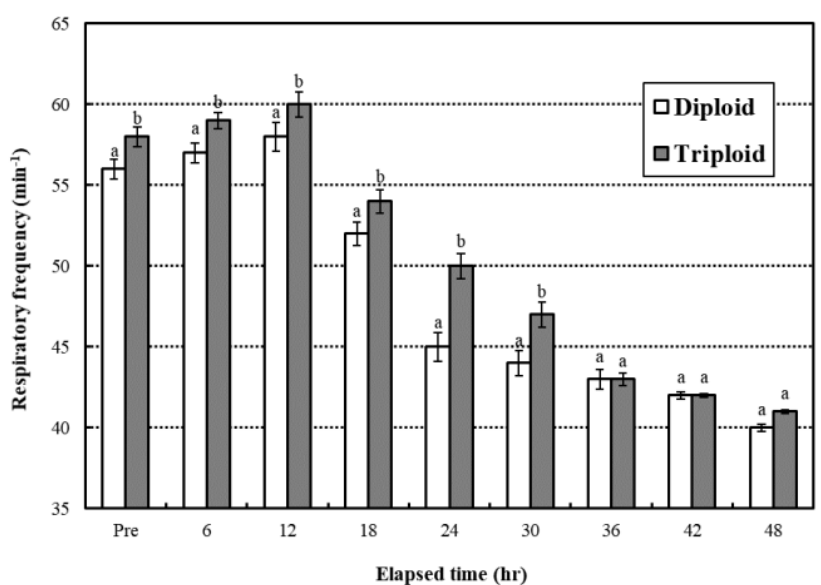

Fig. 1. Respiratory frequency (gill cover movement) between diploid and triploid far eastern catfish, $\mathrm{Si}$ lurus asotus in this experiment. Respiratory frequency of each sample were measured while $1 \mathrm{mi}-$ nute. 'Pre' in X-axis means that respiratory frequency was measured before experiment. Different letters on the bars indicate statistical significance $(p<0.05)$. Values represent means $\pm \mathrm{SE}$ of triplicate experiment $(n=30)$.

During the low water temperature stress test, the $\mathrm{CO}_{2}$ concentrations increased dramatically until $30 \mathrm{hrs}$ and then increased gradually until $48 \mathrm{hrs}$, respectively (Table 1). The $\mathrm{CO}_{2}$ concentration was not significantly different between diploid and triploid during 6 hrs $(p>0.05)$. After 6 hrs, the $\mathrm{CO}_{2}$ concentrations were affected by ploidy, and the $\mathrm{CO}_{2}$ concentrations of diploid were significantly higher than triploid while $42 \mathrm{hrs}(p<0.05)$. The $\mathrm{NH}_{4}{ }^{+}$concentrations increased dramatically until $24 \mathrm{hrs}$ and then increased gradually until $48 \mathrm{hrs}$, respectively (Table 1). The $\mathrm{NH}_{4}{ }^{+}$ concentrations of diploid were higher than triploid during experimental period $(p<0.05)$. The $\mathrm{pH}$ decreased dramatically until $12 \mathrm{hrs}$ and then decreased gradually until $48 \mathrm{hrs,}$ respectively (Table 1). The $\mathrm{pH}$ values of diploid were lower than triploid during experimental period $(p<0.05)$.

The oxygen consumption increased until $12 \mathrm{hrs}$ and then decreased gradually until 48 hrs, respectively (Fig. 2). The oxygen consumption rates were not affected by ploidy $(p>0.05)$, and the oxygen consumption rates of diploid 
Table 1. Carbon dioxide $\left(\mathrm{CO}_{2}\right)$, ammonium $\left(\mathrm{NH}_{4}{ }^{+}\right)$concentrations and $\mathrm{pH}$ values between diploid and triploid far eastern catfish, Silurus asotus in this experiment

\begin{tabular}{|c|c|c|c|c|c|c|}
\hline \multirow{3}{*}{$\begin{array}{c}\text { Time } \\
\text { (hours) }\end{array}$} & \multicolumn{6}{|c|}{ Measurements } \\
\hline & \multicolumn{2}{|c|}{$\mathrm{CO}_{2}$ concentration $(\mathrm{mg} / \mathrm{L})$} & \multicolumn{2}{|c|}{ Ammonium $\left(\mathrm{NH}_{4}^{+}\right)$} & \multicolumn{2}{|c|}{$\mathrm{pH}$} \\
\hline & Diploid & Triploid & Diploid & Triploid & Diploid & Triploid \\
\hline Pre-experiment & $05.1^{3}$ & $05.1^{3}$ & 0 & 0 & $7.6^{1}$ & $7.6^{\mathrm{b}}$ \\
\hline 6 & $13.6^{\mathrm{a}}$ & $13.0^{\mathrm{a}}$ & $0.11^{\mathrm{b}}$ & $0.08^{\mathrm{a}}$ & $6.8^{\mathrm{a}}$ & $7.2^{\mathrm{b}}$ \\
\hline 12 & $15.2^{\mathrm{b}}$ & $14.6^{\mathrm{a}}$ & $0.14^{\mathrm{b}}$ & $0.11^{\mathrm{a}}$ & $4.1^{\mathrm{a}}$ & $4.9^{\mathrm{b}}$ \\
\hline 18 & $17.6^{\mathrm{b}}$ & $16.4^{\mathrm{a}}$ & $0.17^{\mathrm{b}}$ & $0.14^{\mathrm{a}}$ & $3.7^{\mathrm{a}}$ & $4.6^{\mathrm{b}}$ \\
\hline 24 & $19.2^{\mathrm{b}}$ & $18.6^{\mathrm{a}}$ & $0.18^{\mathrm{b}}$ & $0.16^{\mathrm{a}}$ & $3.5^{\mathrm{a}}$ & $4.3^{\mathrm{b}}$ \\
\hline 30 & $20.8^{\mathrm{b}}$ & $19.4^{\mathrm{a}}$ & $0.20^{\mathrm{b}}$ & $0.17^{\mathrm{a}}$ & $3.2^{\mathrm{a}}$ & $3.9^{\mathrm{b}}$ \\
\hline 36 & $21.4^{\mathrm{b}}$ & $20.0^{\mathrm{a}}$ & $0.22^{\mathrm{b}}$ & $0.18^{\mathrm{a}}$ & $3.0^{\mathrm{a}}$ & $3.7^{\mathrm{b}}$ \\
\hline 42 & $22.0^{\mathrm{b}}$ & $20.4^{\mathrm{a}}$ & $0.24^{\mathrm{b}}$ & $0.19^{\mathrm{a}}$ & $2.9^{\mathrm{a}}$ & $3.5^{\mathrm{b}}$ \\
\hline 48 & $23.4^{\mathrm{b}}$ & $20.6^{\mathrm{b}}$ & $0.25^{\mathrm{b}}$ & $0.20^{\mathrm{a}}$ & $2.8^{\mathrm{a}}$ & $3.4^{\mathrm{b}}$ \\
\hline
\end{tabular}

The values are means of triplicate groups $(n=100)$.

Differences between diploid and triploid are significant at this level $(p<0.05)$.

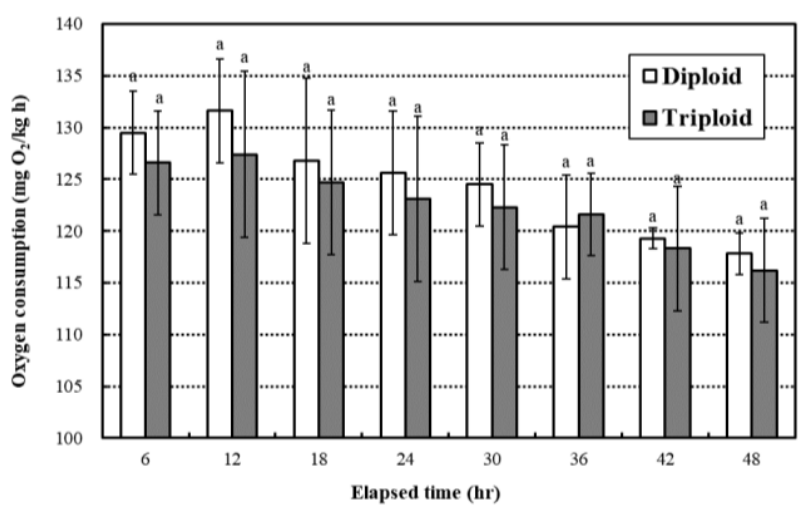

Fig. 2. Oxygen consumption between diploid and triploid far eastern catfish, Silurus asotus in this experiment. Different letters on the bars indicate statistical significance $(p<0.05)$. Values represent means \pm SE of triplicate experiment $(n=30)$.

were not significantly higher or lower than those of triploid in all measurement times $(p>0.05)$. The oxygen consumption rates of diploid and triploid were $131.6 \pm 5.04 \mathrm{mgO}_{2} /$ $\mathrm{kg} \cdot \mathrm{h}$ and $127.4 \pm 8.10 \mathrm{mgO}_{2} / \mathrm{kg} \cdot \mathrm{h}$ in $12 \mathrm{hrs}$, and $117.8 \pm 2.21$ $\mathrm{mgO}_{2} / \mathrm{kg} \cdot \mathrm{h}$ and $116.2 \pm 5.25 \mathrm{mgO} / \mathrm{kg} \cdot \mathrm{h}$ in $48 \mathrm{hrs}$, respec- tively. So, the differential of oxygen consumption rates between diploid and triploid was decreased over measurement time.

The average cortisol concentration between diploid and triploid from the low water temperature stress test is shown in the Fig. 3. The average cortisol concentration of control groups were $0.80 \mu \mathrm{g} / \mathrm{dL}, 0.71 \mu \mathrm{g} / \mathrm{dL}$, respectably and has been rapidly increased to $14.76 \mu \mathrm{g} / \mathrm{dL}, 10.49 \mu \mathrm{g} / \mathrm{dL}$ in $1 \mathrm{hr}$ of low temperature exposure and became $22.09 \mu \mathrm{g} / \mathrm{dL}$, $17.66 \mu \mathrm{g} / \mathrm{dL}$ in $6 \mathrm{hrs}$. After $12 \mathrm{hrs}$ of low temperature exposure, it became $30.43 \mu \mathrm{g} / \mathrm{dL}, 5.39 \mu \mathrm{g} / \mathrm{dL}$, respectably so that the cortisol concentration of diploid increased while triploid decreased rapidly. In $24 \mathrm{hrs,} \mathrm{concentrations} \mathrm{be-}$ came $5.38 \mu \mathrm{g} / \mathrm{dL}, 5.27 \mu \mathrm{g} / \mathrm{dL}$ so the cortisol concentrations rapidly decreased for 2 diploid while 3 triploid had hardly any changes. In $48 \mathrm{hrs}$, the concentrations became 4.60 $\mu \mathrm{g} / \mathrm{dL}, 4.53 \mu \mathrm{g} / \mathrm{dL}$, respectively. Diploid and triploid groups had little reduction, but there was no significant difference in exposure times $(p>0.05)$. According to the exposure 


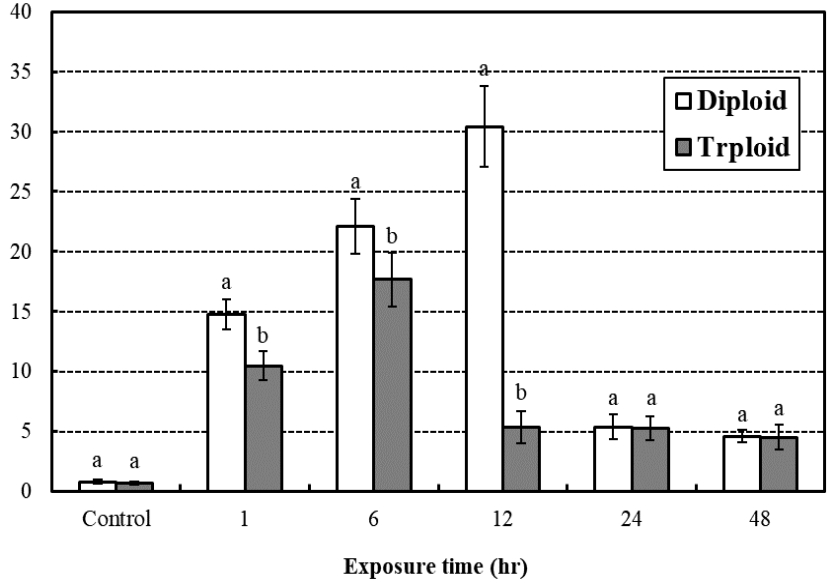

Fig. 3. Plasma cortisol concentration variations in blood plasma of diploid and triploid far eastern catfish, Silurus asotus during 48 hrs of low water temperature stress period. Values represent means \pm SE of triplicate experiment $(n=30)$. Actually $n=5$ for each experiment because mean and SE are calculated separately for each group.

time, cortisol concentrations of all measurement times were significant differences between diploid and triploid $(p<0.05)$, and the cortisol concentration of triploid was generally lower than that of diploid $(p<0.05)$. The diploid showed the highest cortisol concentration in $12 \mathrm{hrs}$ of low temperature exposure and the triploid had the highest cortisol concentration in $6 \mathrm{hrs}$ of low temperature exposure.

The average concentration of plasma glucose between diploid and triploid at the low water temperature stress test is seen in Fig. 4. The average plasma glucose concentrations of control groups were $29 \mathrm{mg} / \mathrm{dL}, 30 \mathrm{mg} / \mathrm{dL}$ and significantly increased to $68 \mathrm{mg} / \mathrm{dL}, 53 \mathrm{mg} / \mathrm{dL}$ in a $\mathrm{hr}$ and became $73 \mathrm{mg} / \mathrm{dL}, 60 \mathrm{mg} / \mathrm{dL}$ after $6 \mathrm{hrs}$, respectively. The concentration rapidly increased to $235 \mathrm{mg} / \mathrm{dL}, 130 \mathrm{mg} / \mathrm{dL}$ in $12 \mathrm{hrs}$ and rapidly decreased to $143 \mathrm{mg} / \mathrm{dL}, 55 \mathrm{mg} / \mathrm{dL}$ in $24 \mathrm{hrs}$, respectively. In $48 \mathrm{hrs}$, it decreased to $33 \mathrm{mg} / \mathrm{dL}$, $41 \mathrm{mg} / \mathrm{dL}$, respectively. In general, there was significant difference between diploid and triploid and the general plasma glucose concentration of triploid was lower than those of the diploid $(p<0.05)$. The highest plasma glucose concentrations of them were seen at $12 \mathrm{hrs}$ after the test.

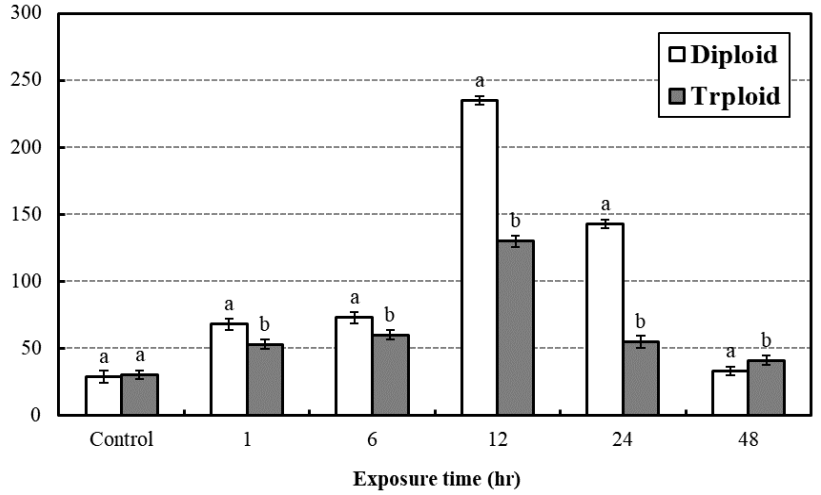

Fig. 4. Plasma glucose concentration variations in blood plasma of diploid and triploid far eastern catfish, Silurus asotus during 48 hrs of low water temperature stress period. Values represent means \pm SE of triplicate experiment ( $n=30)$. Actually $n=5$ for each experiment because mean and SE are calculated separately for each group.

In case of lactic acid, there were no significantly difference between diploid and triploid during low water temperature stress test (Fig. 5). In $24 \mathrm{hrs,} \mathrm{the} \mathrm{lactic} \mathrm{acid} \mathrm{con-}$ centration of diploid and triploid was highest $2.61 \mathrm{mmol} / \mathrm{L}$, $2.60 \mathrm{mmol} / \mathrm{L}$ for the low temperature exposure, respectively $(p<0.05)$. In the study, our results show the tendency that

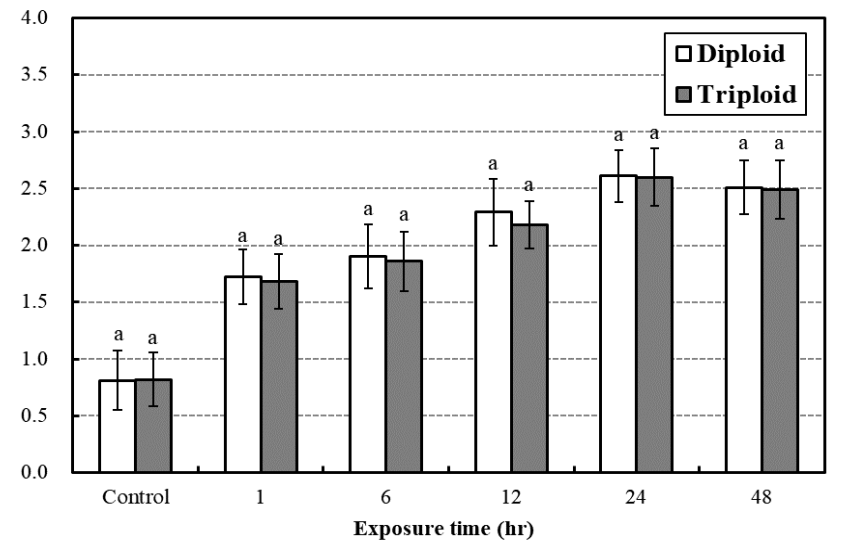

Fig. 5. Plasma lactic acid concentration variations in blood plasma of diploid and triploid far eastern catfish, Silurus asotus during 48 hrs of low water temperature stress period. Values represent means \pm SE of triplicate experiment ( $n=30)$. Actually $n=5$ for each experiment because mean and SE are calculated separately for each group. 
plasma cortisol level increased faster than glucose and lactic acid concentrations and plasma glucose concentrations increased faster than lactic acid in both diploid and triploid far eastern catfish.

\section{DISCUSSION}

In this study, $\mathrm{CO}_{2}$ and $\mathrm{NH}_{4}{ }^{+}$concentrations of diploid far eastern catfish, Silurus asotus had higher values than those of triploid, and the respiratory frequencies and $\mathrm{pH}$ values of diploid were lower than triploid during low water temperature stress test. The oxygen consumption rates were not significantly different between diploid and triploid. The result of this study was similar to previous study of Seol et al. (2008), who reported that the oxygen consumption rate did not differ significantly between diploid and triploid far eastern catfish. The respiratory frequency of triploid far eastern catfish was higher than diploid, so the respiratory function of triploid was lower than diploid (Seol et al., 2008). As noted by Benfey (1999), numerous studies have shown that oxygen consumption rates are similar for triploids and diploids under a variety of experimental conditions (Oliva-Teles \& Kaushik, 1987; Aliah et al., 1991). However, we have found previous studies that contrast with this study. Stillwell \& Benfey (1996) found that the triploid brook trout, Salvelinus fontinalis, had a lower oxygen consumption rate than the diploid fish. Oliva-Teles \& Kaushik (1987) examined triploid rainbow trout, Oncorhynchus mykiss, they produced in two different ways, found that those originating from the retention of the second polar body (the most common way of producing triploids, triploid far eastern catfish were induced by this method: Benfey, 1999) had higher oxygen consumption rates than diploids or triploids that originated from diploid - tetraploid crosses, which had intermediate oxygen consumption rates. Few of these studies can be compared because of differences in the sizes and stages of development of the fish studied and in their levels of activity both before and during the oxygen consumption measurements. The importance of controlling for activity, sex, and maturity in studies of triploid hematology, respiratory and physiology has been outlined by Stillwell \& Benfey (1996). The opercular abduction rate at a given oxygen consumption rate, a measure of respiratory system efficiency, has been shown to be the same for triploids and diploids in some studies (Aliah et al., 1991; Stillwell \& Benfey, 1996), but higher for triploids in many other studies (Sezaki et al., 1991).

The trends in plasma cortisol, plasma glucose and lactic acid concentrations of diploid and triploid far eastern catfish observed in this experiment are indicative of stressed reactions. Plasma cortisol and plasma glucose are recognized as useful indicators of stress in fish (Schreck, 1982). As expected trends in plasma cortisol levels increased significantly at the beginning of a chronic stress situation (Barton \& Iwama, 1991) but then declined back to initial values thereafter (Tort et al., 1996). Our results that plasma cortisol level increased faster than glucose and lactic acid concentrations, and plasma glucose concentrations increased faster than lactic acid was similar to a study carried out by Park et al. $(2008,2009)$.

Plasma cortisol and glucose levels in red drum Sciaenops ocellatus, simultaneously exposed to MS-222 and Quinaldine anesthetic, were reported to be elevated (Massee et al., 1995). Barton \& Iwama (1991) stated that "Usually, phenomenon that plasma cortisol concentration of fishes rises by stress is first order reaction, phenomenon that plasma glucose concentration rises is result of secondorder first order reaction by hormone rise reaction by stress.". This trend has been reported in the gray mullet Mugil cephalus and kelp grouper Epinephelus bruneus (Park et al., 2008). Das et al. (2004) suggested that the greater use of glucose for increased cell metabolism during early exposure may have overwhelmed the increase in blood glucose, even though glycogenolysis would have increased during this period (Martinez-Alvarez et al., 2002). However, because of dysfunctional cell metabolism 
the lower use of glucose later in the exposure period (after $48 \mathrm{hrs}$ ) resulted in an increase in blood glucose levels. One of the more traditional stress indicators has been blood lactic acid (Pickering \& Pottinger, 1989). If experimental animal was added to chronic stress, then result of lactic acid concentration is high (Wedemeyer et al., 1990). The accumulation of lactic acid in muscle or blood (hyperlacticemia) is now well accepted as an indicator of anaerobic metabolism due to fright or severe exertion (Turner et al., 1983). However, the view that lactic acidosis is the ultimate cause of death that sometimes occurs after severe exercise has been challenged (Wood et al., 1983).

The only controlled experiment to have assessed physiological aspects of the stress response of triploid is that of Biron \& Benfey (1994), who found no difference between triploids and diploids in hematocrit and plasma cortisol and glucose profiles after an acute handling stress. In light of abundant anecdotal information that triploids do not cope well with poor water quality, a common source of chronic stress in aquaculture, detailed study of the response of triploids to chronic stress is warranted. Poorer survival due to chronic stress may be reflected in reduced energy stores and/or increased rates of depletion of these stores during stressful conditions. Although substrate utilization during aerobic metabolism does not differ between triploids and diploids, it may be that triploids differ in their ability to withstand sustained anaerobic metabolism (Ojolick et al., 1995).

Considering the results of this research, diploid has slower respiratory frequencies, releasing higher $\mathrm{CO}_{2}$ and $\mathrm{NH}_{4}{ }^{+}$concentrations and causing faster acidification of water, and oxygen consumption rate was not different between diploid and triploid. In the same concentrations of dissolved oxygen, diploid were more used oxygen efficiently than triploid. Because triploid far eastern catfish were characterized by a lower concentration of circulating blood cells (Seol et al., 2008). In this study, oxygen capacities and metabolic abilities of diploids were higher than those of triploids. In low water temperature stress exposure, hormone responses of diploid were more sensitive than those of triploid. So, diploids were more sensitive for stress response than triploids. In this study, stress responses, metabolic ability and oxygen capacities were determined clearly between diploid and triploid. However, relationship between stress response and metabolic ability was not determined clearly in diploid and triploid. Thus, it is necessary to study the difference of physiological response between stress and metabolism in diploid and triploid. So, future investigations in far eastern catfish should focus on relationship between stress and metabolism and comparative physiological reactions between the diploid and the triploid by other stress factor.

\section{ACKNOWLEDGEMENTS}

We thank the staff of the Fishery Genetics and Breeding Sciences Laboratory at Korea Maritime and Ocean University, Korea for their assistance with sampling and data acquisition. Comments from anonymous reviewers greatly improved the quality of this manuscript. All experiments in this study complied with the current laws of Korea (the Law Regarding Experimental Animals, No. 9932).

\section{REFERENGES}

Aliah RS, Inada Y, Yamaoka K, Taniguchi N (1991) Effects of triploidy on hematological characteristics and oxygen consumption of Ayu. Nipp Suis Gakkai 57: 833-836.

Barton BA, Iwama GK (1991) Physiological changes in fish from stress in aquaculture with emphasis on the response and effects of corticosteroids. Annu Rev Fish Dis 1:3-26.

Benfey TJ (1999) The physiology and behavior of triploid fishes. Fish Sci 7:39-67.

Biron M, Benfey TJ (1994) Cortisol, glucose and hemato- 
crit changes during acute stress, cohort sampling, and the diel cycle in diploid and triploid brook trout (Salvelinus fontinalis Mitchill). Fish Physiol Biochem 13:153-160.

Brett JR, Groves TDD (1979) Physiological energetics. In: Hoar WS, Randall DJ (eds) Fish Physiology, Vol. 8. New York: Academic Press, pp 279-352.

Choi GC, Kim DS, Jo JY, Kim JM (1992) Induced breeding and indoor culture of the catfish, Silurus asotus (Teleostomi : Siluridae). J Aquacult 5:117-126.

Daoud D, Chabot D, Audet C, Lambert Y (2007) Temperature induced variation in oxygen consumption of juvenile and adult stages of the Northern shrimp, Pandalus borealis. J Exp Mar Biol Ecol 347:30-40.

Das PC, Ayyappan S, Jena JK, Das BK (2004) Nitrite toxicity in Cirrhinus mrigala (Ham.): acute toxicity and sub-lethal effect in selected haematological parameters. Aquaculture 235:633-644.

Don J, Avtalion RR (1986) The induction of triploidy in Oreochromis aureus by heat shock. Theor Appl Genet 72:186-192.

Duncan DB (1955) Multiple-range and multiple $F$ tests. Biometrics 11:1-42.

Dunham RA, Devlin RH (1999) Comparison of traditional breeding and transgenesis in farmed fish with implications for growth enhancement and fitness. In: Murray JD, Anderson GB, Oberbauer AM, McGloughlin MN (eds) Transgenic Animals in Agriculture. New York: CAB International, pp 209-229.

Gamperl AK, Wilkinson M, Boutilier RG (1994) $\beta$ Adrenoreceptors in the trout (Oncorhynchus mykiss) heart: Characterization, quantification \& effects of repeated catecholamine exposure. Gen Comp Endocrinol 95:259-272.

Gil HW, Lee TH, Han HJ, Park IS (2017) Comparative analysis of tissue and cell cycle on the far eastern catfish, Silurus asotus between diploid and triploid. Dev Reprod 21:193-204.
Hewitt DR, Irving MG (1990) Oxygen consumption and ammonia excretion of the brown tiger prawn, Penaeus esculentus fed diets of varying protein content. Comp Biochem Physiol 96:373-378.

Kazakov RV, Khalyapina LM (1981) Oxygen consumption of adult Atlantic salmon (Salmo salar L.) males and females in fish culture. Aquaculture 25:289-292.

Kim DS, Cho HJ, Park IS, Choi GC, Nam YK (2001) Cytogenetic traits and gonad development of induced triploidy in Far Eastern catfish (Silurus asotus). Gene Genomics 23:55-62.

Korean Statistical Information Service (2017) http://kosis.kr Li E, Chen L, Zeng C, Chen X, Yu N, Lai Q, Qin JG (2007) Growth, body composition, respiration and ambient ammonia nitrogen tolerance of the juvenile white shrimp, Litopenaeus vannamei, at different salinities. Aquaculture 265:385-390.

Lim SY, Gil HW, Park IS (2017) Change of various characteristics between spawning and non-spawning season in diploid and induced triploid far eastern catfish, Silurus asotus. Dev Repord 21:275-286.

Martinez-Alvarez RM, Hidalgo MC, Domezain A, Morales AE, Grarcia-Gallego M, Sanz A (2002) Physiological changes of sturgeon Acipenser nacarii caused by increasing environmental salinity. J Exp Biol 205: 3699-3706.

Massee KC, Rust MB, Hardy RW, Stickney RR (1995) The effectiveness of tricaine, quinaldine sulfate and metomidate as anesthetics for larval fish. Aquaculture 134:351-359.

Ojolick EJ, Cusack R, Benfey TJ, Kerr SR (1995) Survival and growth of all-female diploid and triploid rainbow trout (Oncorhynchus mykiss) reared at chronic high temperature. Aquaculture 131:177-187.

Oliva-Teles A, Kaushik SJ (1987) Metabolic utilization of diets by polyploid rainbow trout (Salmo gairdneri). Comp Biochem Physiol A Physiol 88:45-47.

Park MO, Hur WJ, Im SY, Seol DW, Lee JH, Park IS 
(2008) Anesthetic efficacy and physiological responses to clove oil - anaestheized kelp grouper, Epinephelus bruneus. Aquac Res 39:877-884.

Park MO, Im SY, Seol DW, Park IS (2009) Efficacy and physiological responses of rock bream, Oplegnathus fasciatus to anesthetization with clove oil. Aquaculture 287:427-430.

Perera E, Diaz-Iglesias E, Fraga I, Carrillo O, Galich GS (2007) Effect of body weight, temperature and feeding on the metabolic rate in the spiny lobster, Panulirus argus (Latreille, 1804). Aquaculture 265:261-270.

Pickering AD, Pottinger TG (1989) Stress responses and diseases resistance in Salmonid fish: Effects of chronic elevation of plasma cortisol. Fish Physiol Biochem $7: 253-258$

Raabo E, Terkildsen TC (1960) On the enzymatic determination of blood glucose. Scandinav J Clin Lab Investigation 12:402-407.

Schreck CB (1982) Stress and rearing of Salmonids. Aquaculture 28:241-249.

Seol DW, Im SY, Hur WJ, Park MO, Kim DS, Jo JY, Park IS (2008) Haematological parameters and respiratory function in diploid and triploid far eastern catfish, Silurus asotus. Gene Genomics 30:205-213.

Sezaki K, Watabe S, Tsukamoto K, Hashimoto K (1991) Effects of increase in ploidy status on respiratory func- tion of ginbuna, Carassius auratus langsdorfii (Cyprinidae). Comp Biochem Physiol A Physiol 99:123-127.

Stillwell EJ, Benfey TJ (1996) Hemoglobin level, metabolic rate, opercular abduction rate and swimming efficiency in female triploid brook trout (Salvelinus fontinalis). Fish Physiol Biochem 15:377-383.

Tave D (1993) Growth of triploid and diploid bighead carp (Hypophthalmichthys nobilis). J Appl Aquacult 2:13-26.

Thompson I, White A, Fletcher TC, Houlihan DF, Secombes CJ (1993) The effect of stress on the immune response of Atlantic salmon (Salmo salar L.) fed diets containing different amounts of vitamin C. Aquaculture 114:1-18.

Tort L, Gomez E, Montero D, Sunyer JO (1996) Serum haemolytic and agglutinating activity as indicators of fish immunocompetence: Their suitability in stress and dietary studies. Aquacult Int 4:31-41.

Turner JD, Wood CM, Clark D (1983) Lactate and proton dynamics in the rainbow trout (Salmo gairdneri). J Exp Biol 104:247-268.

Wedemeyer GA, Barton BA, McLeay DJ (1990) Stress and acclimation. In: Schreck CB, Moyle PB (eds) Methods For Fish Biology. Bethesda, Maryland: American Fishery Society, pp 451-489.

Wood CM, Turner JD, Graham MS (1983) Why do fish die after severe exercise? J Fish Biol 22:189-201. 